\title{
Effect of Laser Settings and Irrigation Rates on Ureteral Temperature During Holmium Laser Lithotripsy, an In Vitro Model
}

\author{
Daniel A. Wollin, MD, ${ }^{1}$ Evan C. Carlos, MD, ${ }^{1}$ Westin R. Tom, BA, ${ }^{2}$ W. Neal Simmons, PhD, \\ Glenn M. Preminger, MD, and Michael E. Lipkin, MD, MBA ${ }^{1}$
}

\begin{abstract}
Purpose: Ureteroscopic laser lithotripsy requires irrigation for adequate visualization and temperature control during treatment of ureteral stones. However, there are little data on how different irrigation and laser settings affect the ureteral wall and surrounding tissues. This effect has become an important consideration with the advent of high-powered lasers. We therefore evaluated the effect of laser settings and irrigation flow on ureteral temperature in an in vitro setting.

Materials and Methods: To mimic ureteroscopic laser lithotripsy, we simulated clinically relevant irrigation flow rates and fired a Holmium:Yttrium-aluminum-garnet (Ho:YAG) laser while monitoring "intraureteral" temperature. The probe tip of a thermometer was placed $1 \mathrm{~mm}$ from the tip of a $200 \mu \mathrm{m}$ laser fiber, which was fired for 60 seconds at $0.2 \mathrm{~J} / 50 \mathrm{~Hz}, 0.6 \mathrm{~J} / 6 \mathrm{~Hz}, 0.8 \mathrm{~J} / 8 \mathrm{~Hz}, 1 \mathrm{~J} / 10 \mathrm{~Hz}$, and $1 \mathrm{~J} / 20 \mathrm{~Hz}$ within a tubing system that allowed for specified room temperature flow rates $(100,50$, and $0 \mathrm{~mL} /$ minute). We recorded temperatures every 5 seconds. The maximum temperature was noted, and each laser/flow trial was duplicated. Averaged maximum temperatures were compared using analysis of variance across irrigation settings.

Results: At $100 \mathrm{cc} /$ minute, only the $1 \mathrm{~J} / 20 \mathrm{~Hz}$ laser setting produced a significantly higher maximum temperature $(p<0.01)$, although this finding was not clinically significant at a maximum of $30.7^{\circ} \mathrm{C}$. At a lower irrigation rate of $50 \mathrm{cc} /$ minute, the $1 \mathrm{~J} / 20 \mathrm{~Hz}$ setting was again the only significantly higher maximum temperature $(p<0.05)$, although this temperature crossed the toxic threshold at a maximum of $43.4^{\circ} \mathrm{C}$. With no flow, all maximum temperatures reached over $43^{\circ} \mathrm{C}$, with $0.8 \mathrm{~J} / 8 \mathrm{~Hz}, 1 \mathrm{~J} / 10 \mathrm{~Hz}$, and $1 \mathrm{~J} / 20 \mathrm{~Hz}$ each statistically higher than the lower-energy settings $(p<0.05)$. The maximum temperature at $1 \mathrm{~J} / 20 \mathrm{~Hz}$ with no irrigation was over $100^{\circ} \mathrm{C}$.

Conclusions: Despite increasing laser settings, adequate irrigation can maintain relatively stable temperatures within an in vitro ureteral system. As irrigation rates decrease, even lower power laser settings produce a clinically significant increase in maximum temperature, potentially causing ureteral tissue injury.
\end{abstract}

Keywords: holmium, laser, ureteroscopy, urolithiasis, ureterolithiasis, heat

\section{Introduction}

$\mathbf{U}$ RETEROSCOPY UTILIZING HolmiUM:Yttrium-aluminumgarnet (Ho:YAG) laser technology is the current standard method for intracorporeal lithotripsy of ureteral stones due to its effectiveness of stone fragmentation for all stone types, ease of deflection, and excellent safety profile. ${ }^{1,2}$ Despite such common usage of this technology, little is known regarding the optimal laser parameters for lithotripsy in different settings; many studies have attempted to delineate the advantages and disadvantages of a multitude of laser settings with a variety of results. ${ }^{3,4}$

One of the disadvantages of higher power laser settings, especially given the development of $120 \mathrm{~W}$ laser platforms, is the theoretical risk of thermal tissue injury during ureteroscopic lithotripsy. Tissue injury has been shown to begin at a threshold or "breakpoint" of $43^{\circ} \mathrm{C} .{ }^{5}$ While judicious use of irrigation and careful choice of laser settings may theoretically decrease this risk of thermal injury, no studies have been performed to evaluate the contributions of these variables on

\footnotetext{
${ }^{1}$ Division of Urologic Surgery, Duke University Medical Center, Durham, North Carolina.

${ }^{2}$ Duke University School of Medicine, Durham, North Carolina.

${ }^{3}$ Department of Mechanical Engineering and Materials Science, Duke University, Durham, North Carolina.
} 
temperature change within the operative field. To this end, we sought to utilize an in vitro model to assess the effects of laser settings and irrigation flow on simulated intraureteral temperatures during ureteroscopic Ho:YAG laser lithotripsy.

\section{Materials and Methods}

An in vitro model of ureteroscopic laser lithotripsy was developed to evaluate the temperature changes produced during laser discharge. This system consisted of standard flexible PVC irrigation tubing with a regulating roller clamp connected to a $3-\mathrm{L}$ saline bag. Irrigation flow through the tubing with gravity drainage was measured at different clamp positions to allow for reproducible irrigation rates that have been noted as clinically relevant during ureteroscopic laser lithotripsy. An unused, uncleaved, unstripped $200 \mu \mathrm{m}$ Flexiva TracTip laser fiber (Boston Scientific, Marlborough, MA) connected to a Lumenis Pulse $100 \mathrm{~W}$ Ho:YAG laser (Lumenis, Yokneam, Israel) was passed into the tubing and secured in position within the center of the $15 \mathrm{~F}$ lumen. A multilogger thermometer (OMEGA Engineering, Stamford, CT) was positioned with the probe $1 \mathrm{~mm}$ from the tip of the laser fiber and secured at this location (Fig. 1).

Under a set room temperature irrigation parameter $(0,50$, and $100 \mathrm{cc} / \mathrm{minute}$ ), the laser was fired for 60 seconds at a specified laser setting, with the entire system starting at room temperature. Temperatures were monitored continuously with values logged at 5-second intervals; in addition, the overall maximum temperature was documented for each trial. Tested laser settings included $0.2 \mathrm{~J} / 50 \mathrm{~Hz}, 0.6 \mathrm{~J} / 6 \mathrm{~Hz}, 0.8 \mathrm{~J} /$

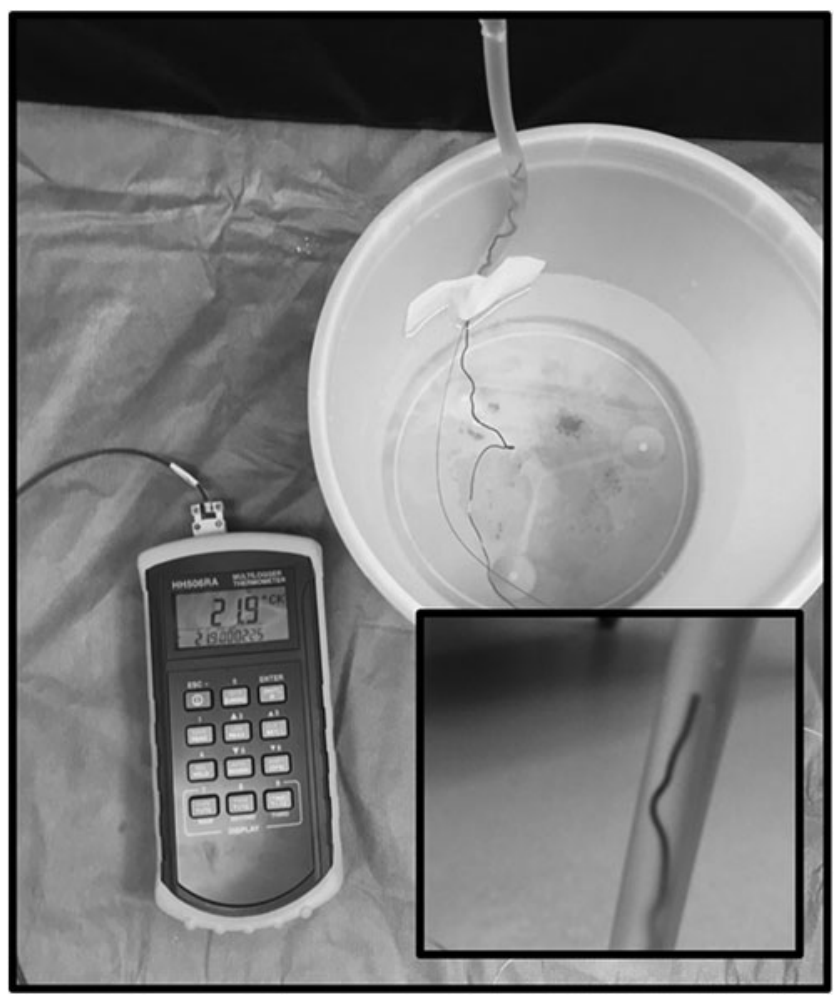

FIG. 1. Experimental setup. PVC tubing with multilogger thermometer and $200 \mu \mathrm{m}$ laser fiber seen within the inset. Irrigation flow was passed down the tubing to allow saline current past the laser as is seen in clinical practice.
$8 \mathrm{~Hz}, 1 \mathrm{~J} / 10 \mathrm{~Hz}$, and $1 \mathrm{~J} / 20 \mathrm{~Hz}$. Each laser and flow setting combination was tested in duplicate.

\section{Results}

During the 60 -second window of lasing time, the Ho:YAG laser produced different temperature curves based on the irrigation rate utilized (Fig. 2). With $100 \mathrm{cc} /$ minute of irrigation, there is minimal rise in temperature across all laser settings. Once the irrigation is decreased to $50 \mathrm{cc} /$ minute, these temperatures remain low, except for a small and temporary increase as much as $43.4^{\circ} \mathrm{C}$ seen in one of two runs with the $1 \mathrm{~J} / 20 \mathrm{~Hz}$ setting. With no irrigation, there is a more dramatic increase in temperature; while $0.2 \mathrm{~J} / 50 \mathrm{~Hz}$ and $0.6 \mathrm{~J} /$ $6 \mathrm{~Hz}$ stay below $50^{\circ} \mathrm{C}$, the other laser settings generate temperatures that reach considerably higher levels. Of note, the time points at 55 and 60 seconds on the $1 \mathrm{~J} / 20 \mathrm{~Hz}$ curve are absent due to boiling within the irrigation column as the fluid temperature peaked over $100^{\circ} \mathrm{C}$.

The maximum temperatures were compared between laser settings at each irrigation rate (Fig. 3). At a rate of $100 \mathrm{cc} /$ minute, the maximum temperature reached with $1 \mathrm{~J} / 20 \mathrm{~Hz}$ $\left(30.7^{\circ} \mathrm{C}\right)$ was significantly higher than the other laser settings $(p<0.01)$. At the middle rate of $50 \mathrm{cc} /$ minute, $1 \mathrm{~J} / 20 \mathrm{~Hz}$ again produced a significantly higher maximum temperature of $43.4^{\circ} \mathrm{C}$ compared to the other settings $(p<0.05)$. With no irrigation, the $0.8 \mathrm{~J} / 8 \mathrm{~Hz}, 1 \mathrm{~J} / 10 \mathrm{~Hz}$, and $1 \mathrm{~J} / 20 \mathrm{~Hz}$ settings all generated significantly higher temperatures than the other laser parameters $(p<0.05)$. Of note, all laser settings produced a maximum temperature above $43^{\circ} \mathrm{C}$ when no irrigation was used.

\section{Discussion}

Ureteroscopic Ho:YAG laser lithotripsy serves as an efficient and relatively safe surgical intervention for ureteral stone removal. Intraoperative complications are infrequent, occurring in $3 \%$ to $5 \%$ of cases. ${ }^{6,7}$ However, laser thermal injuries can occur. The Ho:YAG laser is absorbed by water and, therefore, has a short thermal injury zone of 0.5 to $1 \mathrm{~mm} .{ }^{8}$ However, using just $5 \mathrm{~W}(0.5 \mathrm{~J}$ at $10 \mathrm{~Hz})$ of power a group demonstrated that when $0.5 \mathrm{~mm}$ away, a Ho:YAG laser perforated ex vivo porcine ureter in an average of just 2 seconds. ${ }^{9}$ Ureteral perforations can lead to prolonged ureteral stenting, reoperation, and ureteral stricture formation. ${ }^{10,11}$ Ho:YAG lasers are long-pulsed and operate primarily by a photothermal effect without producing large amounts of photoacoustic energy. ${ }^{12}$ As such, Ho:YAG-related ureteral injury is likely a direct result from super-heated tissue; hence, our impetus for this study.

Saline irrigation has been suggested as a means for temperature regulation during Ho:YAG lithotripsy. ${ }^{13}$ As irrigant passes over tissue, stone, and urine surrounding the laser, heat is transferred to the irrigant by convection, which is the transfer of heat from a body to bulk fluid in motion.

Other studies have also shown Ho:YAG lasers to produce potentially dangerous temperatures. An in vitro study compared temperatures generated by Thulium:Yttriumaluminum-garnet (Tm:YAG) and Ho:YAG in an upper tract model. ${ }^{14}$ Their setup included a saline-filled cup containing the laser of interest and a temperature probe with a vertical burette above to provide irrigation. Results ranged between $45.6^{\circ} \mathrm{C}$ and $68.7^{\circ} \mathrm{C}$ across all flow rates $(2,5,10$, and 

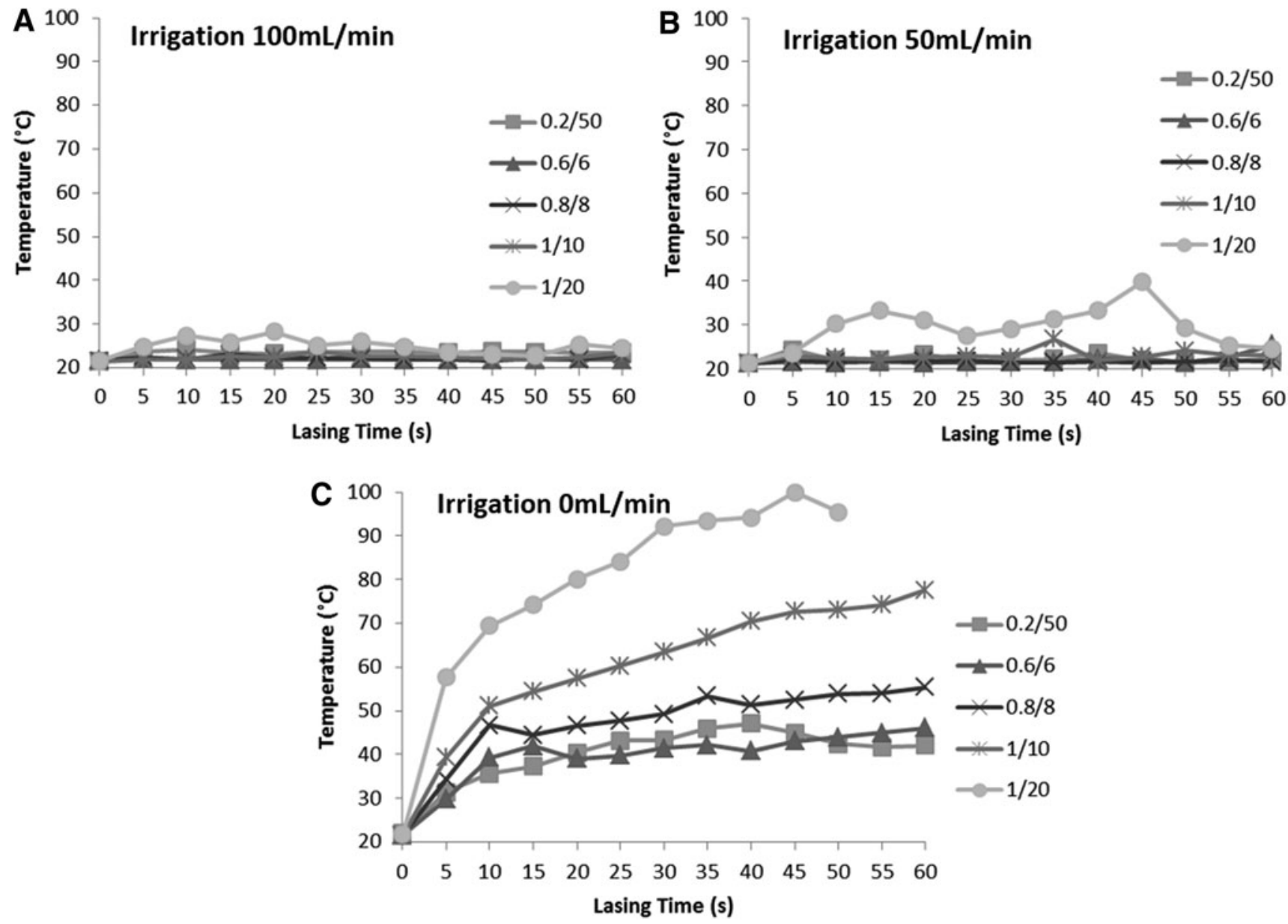

FIG. 2. Temperatures produced during constant Ho:YAG laser firing in a ureteral model with various laser and irrigation settings. (A) Irrigation flow of $100 \mathrm{cc} /$ minute. (B) Irrigation flow of $50 \mathrm{cc} /$ minute. (C) Irrigation flow of $0 \mathrm{cc} /$ minute. All laser settings expressed as $\mathrm{J} / \mathrm{Hz}$. Ho:YAG $=$ Holmium:Yttrium-aluminum-garnet.

$25 \mathrm{cc} / \mathrm{minute})$ and power settings $(5,10$, and $20 \mathrm{~W})$. In the end, Tm:YAG was determined to be no different than Ho:YAG. While their model did compare the two lasers, it did not have fluid flowing across the laser as ours did. Without flowing irrigant, heat transfer by convection was incompletely simulated. Therefore, the fact that temperatures were above $43^{\circ} \mathrm{C}$ regardless of flow rate should be considered relative to the data we accrued with irrigation flowing past across the laser, as is seen clinically.

Another group used ex vivo sheep ureters and fired a Ho:YAG laser at calcium oxalate calculi with a $365 \mu \mathrm{m}$ fiber at $1 \mathrm{~J} / 10 \mathrm{~Hz}$ for 3 seconds. ${ }^{13} \mathrm{~A}$ subset of experiments involved laser lithotripsy in an intact sheep ureter either receiving saline irrigation at $8 \mathrm{cc} / \mathrm{second}$ (480 cc/minute) or none at all. The nonirrigation group temperatures were significantly higher than the irrigation group's, which were $49.5^{\circ} \mathrm{C} \pm 2.3^{\circ} \mathrm{C}$ and $37.4^{\circ} \mathrm{C} \pm 2.5^{\circ} \mathrm{C}$, respectively. While this finding does underscore the role of irrigation in temperature stabilization during ureteroscopy, it does so outside of clinical parameters. A flow rate of $480 \mathrm{cc} / \mathrm{minute}$ is well above the 0 to $150 \mathrm{cc} / \mathrm{minute}$ that is typically used and likely above the possibilities through the 3.3 to $3.6 \mathrm{~F}$ irrigation port seen in most modern ureteroscopes. In addition, in our experience the Ho:YAG laser is fired in bursts lasting longer than 3 seconds.
As such, we performed our study at the aforementioned flow rates while firing the laser for 60 seconds.

It is our practice to use an automated fluid pump (Thermedx LLC, Cleveland, OH) during ureteroscopy cases. At a prescribed pressure, in real time, the device records the flow rate of irrigation. Through our use of this device, we determined that our standard irrigation pressure of $200 \mathrm{~cm} \mathrm{H}_{2} \mathrm{O}$ commonly outputs a flow of 50 to $100 \mathrm{cc} /$ minute. However, irrigation flow can quickly fall to zero in the case of an obstructing stone or a spent saline supply. Thus, we chose to evaluate each laser setting at 0,50 , and $100 \mathrm{cc} /$ minute. We selected power settings commonly used in our practice to treat ureteral stones. Some may consider $1 \mathrm{~J} / 20 \mathrm{~Hz}$ to be too high powered for a ureteral stone; however, this setting will occasionally be used in certain situations to fragment harder composition ureteral stones and as such was included as a theoretical maximum power setting.

We did identify dangerously high temperatures at all laser settings with the irrigation flow set at zero. The lowest averaged maximum temperatures of $47.1^{\circ} \mathrm{C}$ and $47.2^{\circ} \mathrm{C}$ were seen in the $0.2 \mathrm{~J} / 50 \mathrm{~Hz}$ and $0.6 \mathrm{~J} / 6 \mathrm{~Hz}$ groups, respectively. These temperatures are well above $43^{\circ} \mathrm{C}$, which is considered the breakpoint for exponential thermal cytotoxicity. ${ }^{5}$ In addition, there was a stepwise increase in temperatures as the 

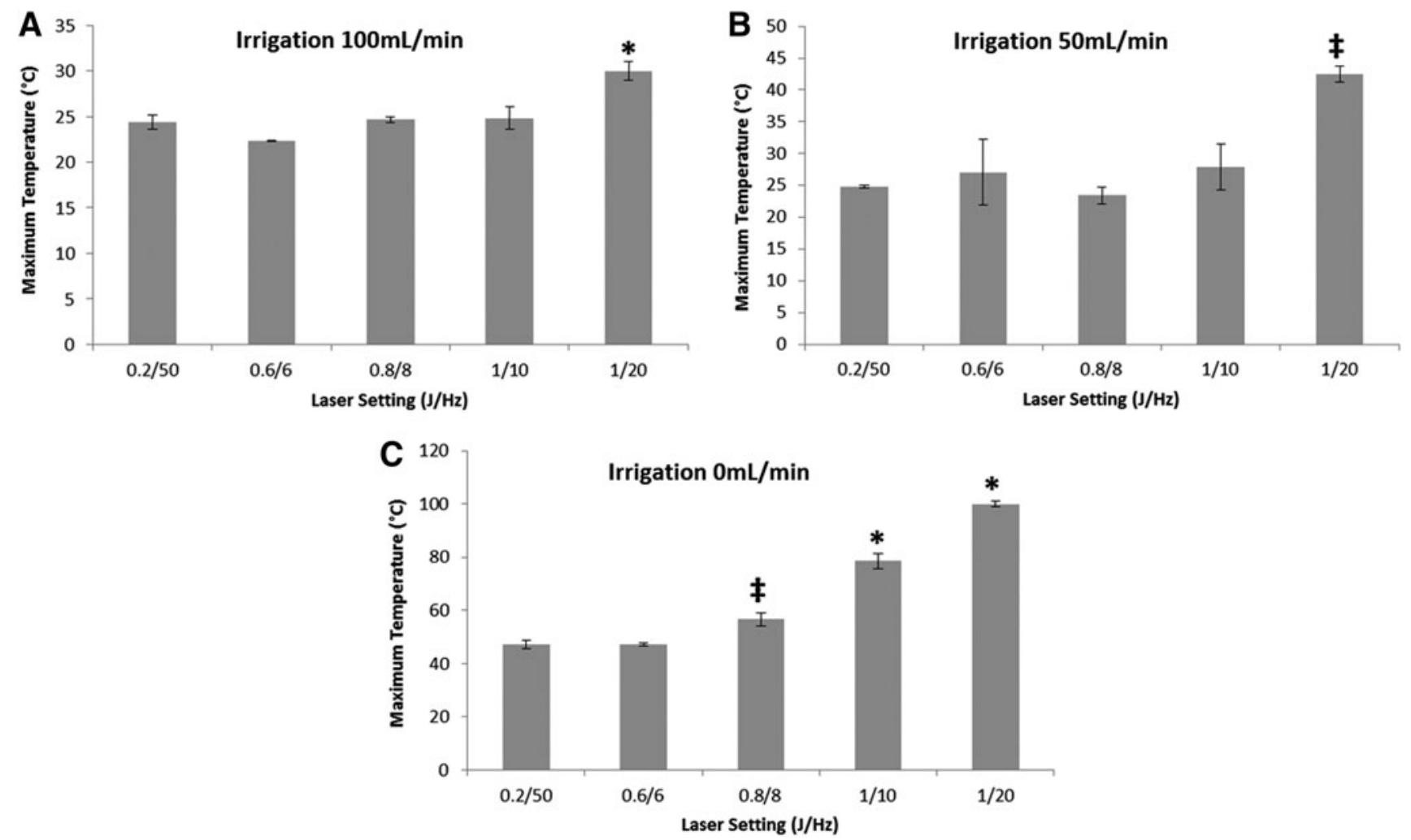

FIG. 3. Maximum temperatures generated during constant Ho:YAG laser firing over 1 minute in a ureteral model. (A) Irrigation flow of $100 \mathrm{cc} /$ minute. ${ }^{*} p<0.01$. (B) Irrigation flow of $50 \mathrm{cc} /$ minute. ${ }^{*} p<0.05$. (C) Irrigation flow of $0 \mathrm{cc} / \mathrm{minute}$. ${ }^{*} p<0.01 ;{ }^{*} p<0.05$.

laser settings increased to $0.8 \mathrm{~J} / 8 \mathrm{~Hz}, 1 \mathrm{~J} / 10 \mathrm{~Hz}$, and then $1 \mathrm{~J} /$ $20 \mathrm{~Hz}$. This result likely occurred because there was no convective heat exchange in the absence of irrigation, which allowed for an absolute transfer of heat from the laser to our simulated ureteral wall. Each of these averaged maximum temperatures was well over the $43^{\circ} \mathrm{C}$ breakpoint. However, cytotoxicity is not limited to reaching a certain temperature threshold alone. Instead, there is time-temperature relationship; for every $1^{\circ} \mathrm{C}$ past $43^{\circ} \mathrm{C}$, the same amount of cell damage occurs in half of the time. ${ }^{5,13}$ For example, cells subjected to $45^{\circ} \mathrm{C}$ for 15 seconds will be exposed to the same degree of cytotoxicity as if they received $44^{\circ} \mathrm{C}$ for 30 seconds or $43^{\circ} \mathrm{C}$ for 1 minute. With this information, it is apparent that utilizing the laser without irrigation flow can rapidly raise ureteral temperatures and as such should be avoided.

Suboptimal or absent irrigation flow can occur for many reasons while firing the Ho:YAG laser during ureteroscopy. A common maneuver to limit stone retropulsion is to decrease or temporarily suspend irrigant flow. Doing so does limit proximal movement of the stone. However, such a tactic should be performed with caution - and with as much flow as possible-considering that the $1 \mathrm{~J} / 20 \mathrm{~Hz}$ setting reached well above $43^{\circ} \mathrm{C}$ after just 5 seconds of laser discharge without flow. Similarly, the $1 \mathrm{~J} / 10 \mathrm{~Hz}$ setting raised temperatures to dangerously high levels after 10 seconds and $0.8 \mathrm{~J} / 8 \mathrm{~Hz}$ after 15 seconds.

Low flow states are often not intentional. Flexible ureteroscopes can buckle at a tight ureteral orifice or a J-hooked ureter. Reduced irrigant flow can also occur when an ob- structing ureteral stone is encountered. If flow issues remain a problem, a ureteral access sheath can be deployed to bolster the scope in the case of kinking or to improve drainage around an obstructing stone. Advanced electronic irrigation devices are helpful as they can monitor flow rates in real time. However, it should be taken into consideration that these devices may overestimate flow rates. ${ }^{15}$

The role of irrigation in heat dispersion is further highlighted in the precipitous drop in simulated ureteral temperatures for the $1 \mathrm{~J} / 20 \mathrm{~Hz}$ setting as irrigation flow increases. At $50 \mathrm{cc} /$ minute this setting did cross the cell damage threshold with a maximum temperature of $43.4^{\circ} \mathrm{C}$. With irrigation at $100 \mathrm{cc} /$ minute, temperatures remained well under $43^{\circ} \mathrm{C}$ with a mean temperature of $30.0^{\circ} \mathrm{C}$. Thus, minimizing laser power and maximizing irrigation flow provide optimal temperature conditions. Each variable can be modified with the understanding that increased thermal risk is a potential consequence; all the while, irrigation flow rates seem to be the more important determinant of temperature in this situation.

We acknowledge that our study has a few notable limitations. First, it can be hard to draw definitive clinical conclusions from an in vitro study. In our benchtop model, the diameter and material of our tubing may not replicate the insular effect of periureteral fat or blood flow, which could carry heat away from the laser's area of interest. Given our findings, we plan to perform a follow-up study in pigs to delineate these effects in an in vivo model.

Another limitation was our use of room temperature irrigation. It is common to use warmed irrigation fluid during 
endourologic cases as there is a demonstrable decrease in the incidence of postoperative hypothermia and shivering when warmed irrigation is used during transurethral resection of the prostate and percutaneous nephrolithotomy. ${ }^{16-18} \mathrm{~A}$ recent benchtop model took temperatures within an ureteroscopy bench-trainer (K-Box; Porgès-Coloplast) immersed in a saline-filled tank. ${ }^{19}$ Irrigation was pressurized to $50 \mathrm{~cm} \mathrm{H}_{2} \mathrm{O}$ at either room temperature $\left(24.5^{\circ} \mathrm{C}\right)$ or body temperature $\left(36.5^{\circ} \mathrm{C}\right)$ and was connected to the experimental setup; the fluid was then allowed to flow through the system or was closed off. The laser was then fired for 5 minutes at $0.5 \mathrm{~J} /$ $20 \mathrm{~Hz}$ and $1 \mathrm{~J} / 10 \mathrm{~Hz}$ and at "fragmentation settings" of 2, 3, and $4 \mathrm{~J}$ at $5 \mathrm{~Hz}$ each. When irrigation was flowing, in both the heated and room temperature boxes, there was no difference in relative temperature increase after about 1 minute of laser activation as each increased by $\sim 1^{\circ} \mathrm{C}$. This finding suggests that the magnitude of temperature increase would not have changed even if we used irrigation at body temperature. From this determination, we can extrapolate that perhaps intraureteral temperatures would be higher and potentially more dangerous when starting from a higher baseline.

\section{Conclusions}

In an in vitro setting, five clinically relevant Ho:YAG laser settings can produce injurious temperatures to ureteral tissue when fired for 60 seconds in the absence of irrigation flow. Temperatures readily dropped to safer levels once saline irrigation was added.

In the age of new stone fragmentation devices and more powerful lasers, we must remain cognizant of potentially detrimental sequelae. Our study has furthered our understanding that adequate irrigation is imperative to safely performing ureteroscopic Ho:YAG laser lithotripsy. We will follow-up this work with an in vivo porcine study to further our investigation into this important issue.

\section{Author Disclosure Statement}

No competing financial interests exist.

\section{References}

1. Türk C, Petř́ík A, Sarica K, Seitz C, Skolarikos A, Straub $\mathrm{M}, \mathrm{Knoll} \mathrm{T}$. EAU guidelines on interventional treatment for urolithiasis. Eur Urol 2016;69:475-482.

2. Pierre S, Preminger GM. Holmium laser for stone management. World J Urol 2007;25:235.

3. Li R, Ruckle D, Keheila M, et al. High-frequency dusting versus conventional holmium laser lithotripsy for intrarenal and ureteral calculi. J Endourol 2017;31:272-277.

4. Kronenberg P, Traxer O. Update on lasers in urology 2014: Current assessment on holmium:yttrium-aluminum-garnet (Ho:YAG) laser lithotripter settings and laser fibers. World J Urol 2015;33:463-469.

5. Thomsen S, Pearce JA. Thermal damage and rate processes in biologic tissues. In: Welch AJ, van Gemert MJ, eds. OpticalThermal Response of Laser-Irradiated Tissue. New York: Plenum Press, 1995, p. 539.

6. Hyams ES, Monga M, Pearle MS, et al. A prospective, multi-institutional study of flexible ureteroscopy for prox- imal ureteral stones smaller than $2 \mathrm{~cm}$. J Urol 2015;193: 165-169.

7. Preminger GM, Tiselius HG, Assimos DG, et al. Guideline for the management of ureteral calculi. J Urol 2007;178: 2418-2424.

8. Wollin TA, Denstedt JD. The holmium laser in urology. J Clin Laser Med Surg 1998;16:13-20.

9. Santa-Cruz RW, Leveillee RJ, Krongrad A. Ex vivo comparison of four lithotripters commonly used in the ureter: What does it take to perforate? 1998;12:417-422.

10. Stoller ML, Wolf JS, Jr, Hofmann R, Marc B. Ureteroscopy without routine balloon dilation: An outcome assessment. J Urol 1992;147:1238-1242.

11. Chang R, Marshall FF. Management of ureteroscopic injuries. J Urol 1987;137:1132-1135.

12. Vassar GJ, Chan KF, Teichman JM, et al. Holmium:YAG lithotripsy: Photothermal mechanism. J Endourol 1999;13: 181-190.

13. Molina WR, Silva IN, Donalisio da Silva R, Gustafson D, Sehrt D, Kim FJ. Influence of saline on temperature profile of laser lithotripsy activation. J Endourol 2015;29: 235-239.

14. Kallidonis P, Amanatides L, Panagopoulos V, et al. Does the heat generation by the Thulium:Yttrium aluminum garnet laser in the irrigation fluid allow its use on the upper urinary tract? J Endourol 2016;30:422-427.

15. De Shubha T, Sarkissian C, Kartha G, Monga M. Evaluating the automated Thermedx fluid management system in a ureteroscopy model. J Endourol 2014;28:549-553.

16. Singh R, Asthana V, Sharma JP, Lal S. Effect of irrigation fluid temperature on core temperature and hemodynamic changes in transurethral resection of prostate under spinal anesthesia. Anesth Essays Res 2014;8:209-215.

17. Monga M, Comeaux B, Roberts JA. Effect of irrigating fluid on perioperative temperature regulation during transurethral prostatectomy. Eur Urol 1996;29:26.

18. Tekgul ZT, Pektas S, Yildirim U, et al. A prospective randomized double-blind study on the effects of the temperature of irrigation solutions on thermoregulation and postoperative complications in percutaneous nephrolithotomy. J Anesth 2015;29:165-169.

19. Butticè $S$, Sener TE, Proietti S, Dragos L, Tefik T, Doizi S, Traxer O. Temperature changes inside the kidney: What happens during Holmium:Yttrium-aluminum-garnet laser usage? J Endourol 2016;30:574-579.

Address correspondence to:

Daniel A. Wollin, MD

Division of Urologic Surgery

Duke University Medical Center

Room 1573 White Zone

Box 3167

Durham, NC 27710

E-mail: daniel.wollin@duke.edu
Abbreviations Used
Ho:YAG = Holmium:Yttrium-aluminum-garnet
Tm:YAG $=$ Thulium:Yttrium-aluminum-garnet 